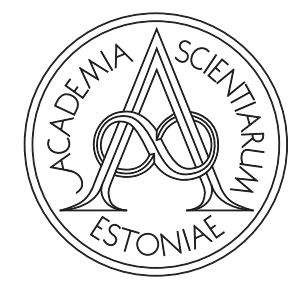

Proceedings of the Estonian Academy of Sciences,

$2021,70,4,500-507$

https://doi.org/10.3176/proc.2021.4.18

Available online at www.eap.ee/proceedings

\title{
The wear of PVD coated elements in oscillation motion at high temperature
}

\author{
Remigiusz Michalczewski ${ }^{a^{*}}$, Marek Kalbarczyk ${ }^{\mathrm{a}, \mathrm{b}}$, Zbigniew Słomka $^{\mathrm{a}}$, Sylwia Sowa ${ }^{\mathrm{a}}$, \\ Maciej Łuszcz ${ }^{a}$, Edyta Osuch-Słomka ${ }^{a}$, Demófilo Maldonado-Cortés ${ }^{\mathrm{c}}$, Le Liu ${ }^{\mathrm{d}}$, \\ Maksim Antonov ${ }^{\mathrm{d}}$ and Irina Hussainova ${ }^{\mathrm{d}}$
}

\begin{abstract}
${ }^{a}$ Lukasiewicz Research Network - Institute for Sustainable Technologies, ul. K. Pułaskiego 6/10, 26-600 Radom, Poland
${ }^{\mathrm{b}}$ Faculty of Mechanical Engineering, Kazimierz Pułaski University of Technology and Humanities in Radom, ul. E. Stasieckiego 54, 26-600 Radom, Poland

${ }^{\text {c }}$ Departamento de Ingeniería, Universidad de Monterrey, Av. Morones Prieto 4500 Pte., 66238 San Pedro Garza García, Mexico

d Department of Mechanical and Industrial Engineering, Tallinn University of Technology, Ehitajate 5, 19086 Tallinn, Estonia
\end{abstract}

Received 14 September 2021, accepted 21 October 2021, available online 9 November 2021

(C) 2021 Authors. This is an Open Access article distributed under the terms and conditions of the Creative Commons AttributionNonCommercial 4.0 International License (http://creativecommons.org/licenses/by-nc/4.0/).

\begin{abstract}
This paper provides an overview on the recent development of coatings and modified surfaces to minimize wear between contact surfaces in high-temperature working environments. The aim of this work was to study the wear of various types of coatings deposited by the PVD (Physical Vapour Deposition) method on $\mathrm{TiB}_{2} / \mathrm{Ti}$ composites manufactured by Spark Plasma Sintering (SPS). The following coatings were investigated: TiN-TiCrN-AlCrN-AlCrTiN/Si ${ }_{3} \mathrm{~N}_{4}$-multilayer, TiN-TiCrN-AlCrN-AlCrTiN/Si $\mathrm{N}_{4}-$ AlCrTiSiN+grad ON, TiN-TiCrN-AlCrN-AlTiCrN and as a reference, a commercially available AlCrN-based coating - all intended to fulfil complex requirements of high-temperature working conditions. The wear tests were performed by means of a ball-on-disc SRV friction and wear tester using reciprocating motion of the $\mathrm{Si}_{3} \mathrm{~N}_{4}$ ball sliding against a coated disc in a wide range of temperatures from room temperature up to $900^{\circ} \mathrm{C}$. The results confirmed that high-temperature wear resistance depends on the proper design of the coatings.
\end{abstract}

Key words: tribology, surface engineering, PVD coating, $\mathrm{TiB}_{2} / \mathrm{Ti}$ composites, SPS, wear.

\section{INTRODUCTION}

Ever-increasing demand for the high performance and long life of machine parts working in severe conditions has been a driver for developing new low-friction and wear resistant coatings and surface modifications. The overall objective of the work was to extend the service life of components operating at high temperatures (HT), in the range of up to $1000{ }^{\circ} \mathrm{C}$, by the development and application of a novel lubrication concept based on the double-lubrication approach, which relies on the design of innovative self-lubricating materials and lubricious multifunctional coatings [1]. $\mathrm{TiB}_{2} / \mathrm{Ti}$ composites manufactured by Spark Plasma Sintering (SPS) are considered as an alternative for tool steels because of their high ability to maintain mechanical properties at high temperature [2]. The benefits of composite substrate usage can be optimized by the deposition of a PVD coating as an additional protection. However, to conduct it in an effective way, it is vital to consider their potential field of implementation at the design stage $[3,4]$. Currently, there is no universal composition and structure of coating that can be effective in a wide range of temperatures $[5,6]$. Some progress has been observed in nanocomposite and

\footnotetext{
*Corresponding author, remigiusz.michalczewski@itee.lukasiewicz.gov.p1
} 
multi-layered coatings. The first of the above mentioned are based on metal nitrides and oxides, and on the blending with solid lubricants such as silver [6]. Multi-layered coatings contain different combinations of hard and lowcohesion layers [7]. The use of a large number of alternating thin layers, forming a multilayer coating, can reduce the propagation of cracks and yield finer grain sizes, leading to higher hardness and improved tribological properties $[8,9]$. The use of multi-layer structure can be a way to increase the adaptability and longevity of coatings for demanding environments.

Three modern coatings were developed, i.e. TiNTiCrNAlCrN-AlCrTiN/Si ${ }_{3} \mathrm{~N}_{4}, \mathrm{TiN}-\mathrm{TiCrN}-\mathrm{AlCrN}-\mathrm{AlCrTiN} / \mathrm{Si}_{3} \mathrm{~N}_{4}-$ AlCrTiSiN+grad ON, TiN-TiCrN-AlCrN-AlTiCrN. As a reference, a commercially available AlCrN-based coating was used. Each of the developed coatings consists of an interlayer responsible for interaction with the substrate (TiN), internal layer (TiCrN-AlCrN, TiCrN-AlCrN plus AlCrTiN-Si ${ }_{3} \mathrm{~N}_{4}$ ) and external layer (structure AlCrTiN/ $\mathrm{Si}_{3} \mathrm{~N}_{4}$, gradient structure AlCrTiSiN $+\mathrm{ON}$, single structure AlTiCrN).

The wear depends on many factors. Therefore, it can be evaluated only in practice, in an experimental manner $[10,11]$. The paper presents the results of research aimed at the selection of the most suitable coating to be used with $\mathrm{TiB}_{2} / \mathrm{Ti}$ composites and dedicated for operation under a high-temperature regime.

\section{MATERIALS AND METHODS}

\section{1. $\mathrm{TiB}_{2} / \mathrm{Ti}$ composites}

On the basis of the previously presented results [12,13], the selection of input powder materials and methods of preparation for ceramic-based bulk $\mathrm{TiB}_{2} / \mathrm{Ti}$ composites,

(a)

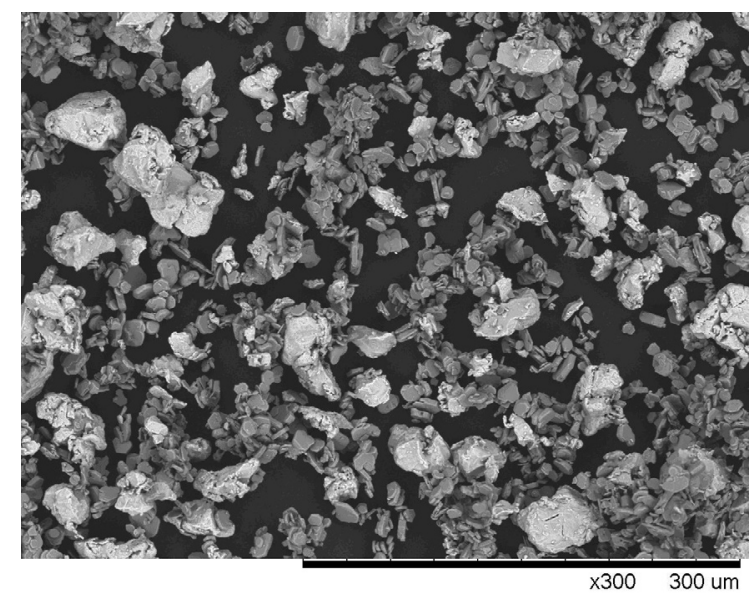

intended for high-temperature PVD coatings, was made. Samples were prepared to obtain the composite with $\mathrm{Ti} / \mathrm{TiB}_{2}$, with the ratio of $15 / 85 \mathrm{wt} \%$ in a fully reacted state. Ceramic titanium diboride plays the role of the hard phase interconnected by metallic titanium. The target $15 / 85$ weight ratio of $\mathrm{Ti} / \mathrm{TiB}_{2}$ corresponds to $\mathrm{Ti} / \mathrm{B}=$ $1.2167 / 1$ molar ratio, hence, the raw powders represent approximately $50 / 50$ weight ratio for $\mathrm{Ti} / \mathrm{TiB}_{2}$. For powder preparation by the self-propagating high-temperature synthesis method (SHS), the elemental titanium and boron powders were used, and the respective $\mathrm{Ti} / \mathrm{B}$ ratio was calculated as 84.3/15.7 wt \%, see Fig. 1a.

The developed powders were consolidated by a spark plasma sintering device (FCT Systeme GmbH, Germany) at $50 \mathrm{MPa}$ pressure with the dwell time of $15 \mathrm{~min}$, the heating rate of $100{ }^{\circ} \mathrm{C}$ per minute, applying sintering temperatures of $1450{ }^{\circ} \mathrm{C}$. The manufactured samples were ca $25 \mathrm{~mm}$ in diameter and $9 \mathrm{~mm}$ in thickness. An image of a typical SPS produced sample is shown in Fig. 1b.

\subsection{Surface finishing}

After removal of the adhered graphite layer adhered during sintering, the samples were numbered using laser engraving and ground to the required thickness $(7.85 \mathrm{~mm})$. In the next step, the samples were polished by means of an automatic polisher. The aim of the polishing process was to obtain a sample surface without extreme irregularities. The average roughness $\left(\mathrm{R}_{\mathrm{a}}\right)$ measured by a noncontact 3D profiler was $0.067 \pm 0.007 \mu \mathrm{m}$. The details of the surface preparation procedure are provided in [13]. For composite materials, the surface preparation is much more complex as compared to steel alloys due to the presence of at least two phases with different mechanical properties and the presence of pores.

(b)

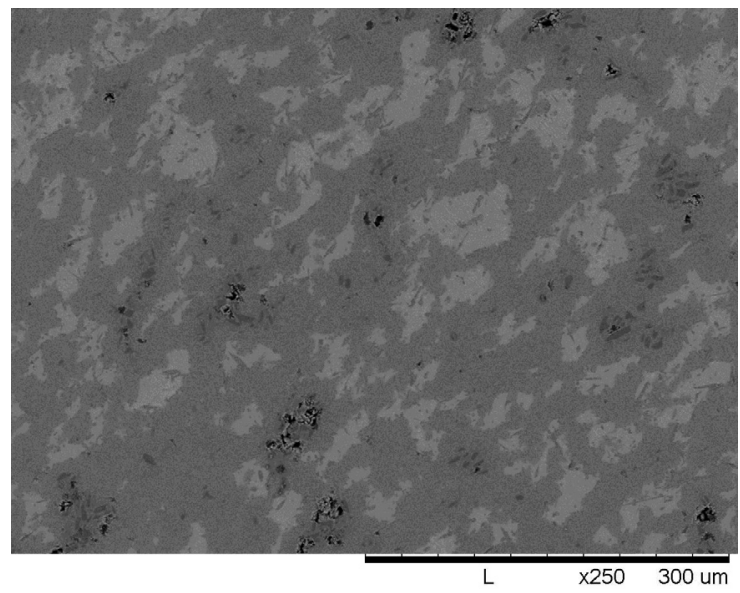

Fig. 1. SEM images of the used powders (a), and the prepared composite samples (b) [13]. 


\subsection{Coating deposition}

Four types of PVD coatings were deposited on the flat surface of the discs made of $\mathrm{TiB}_{2} / \mathrm{Ti}$ composite manufactured according to the technology described in section 2.1 and with the surface finishing presented in section 2.2. The first one, denoted as "Coating A" represents the AlCrN-based commercial coating (BALINIT ${ }^{\circledR}$ ALCRONA PRO made by Oerlikon Balzers). The detailed deposition process parameters are not provided by the coating supplier. The selected coating exhibits excellent tribological characteristics at temperatures up to $1100{ }^{\circ} \mathrm{C}[14]$. The chemical composition of the coating, measured by X-ray microprobe EDS, is $36.9 \pm 0.2 \mathrm{at} \% \mathrm{Al}$, $39.1 \pm 0.2 \mathrm{at} \% \mathrm{Cr}$ and $21.2 \pm 0.3 \mathrm{at} \% \mathrm{~N}$. The thickness of the coating is ca $1.2 \mu \mathrm{m}$.

Three types of multilayer PVD coatings developed at the Lukasiewicz-ITeE Surface Engineering Centre were deposited using the PLATIT Pi411 PLUS device and the PVD arc deposition method. They are denoted as "Coating B", "Coating C", and "Coating D". The structure of the coatings visible in the craters after Calo test measurements is presented in Fig. 2.

The Coating B structure (from the substrate) is: TiNTiCrN-AlCrN-AlCrTiN/ $/ \mathrm{Si}_{3} \mathrm{~N}_{4}-$ Fig. 2a. The total thickness of the coating is $4.4 \mu \mathrm{m}$. The TiN layer (1) is ca $0.2 \mu \mathrm{m}$ thick, the TiCrN-AlCrN middle structure (2) has $3.0 \mu \mathrm{m}$, and the external structure of $\mathrm{AlCrTiN} / \mathrm{Si}_{3} \mathrm{~N}_{4}(3)$ has $1.2 \mu \mathrm{m}$ of thickness.

The Coating $\mathrm{C}$ structure (from the substrate) is: TiNTiCrN-AlCrN-AlCrTiN $/ \mathrm{Si}_{3} \mathrm{~N}_{4}-\mathrm{AlCrTiSiN}+\operatorname{grad} \mathrm{ON}-$ Fig. 2b. The total thickness of the coating is $5.8 \mu \mathrm{m}$. The TiN layer (1) is ca $0.5 \mu \mathrm{m}$ thick, the second TiCrN-AlCrN (2) is $2.8 \mu \mathrm{m}$, the third AlCrTiN- $\mathrm{Si}_{3} \mathrm{~N}_{4}$ layer (3) is $1.4 \mu \mathrm{m}$ and the external gradient structure AlCrTiSiN+ON (4) layer is $1.2 \mu \mathrm{m}$ thick.

The Coating D structure (from the substrate) is: TiNTiCrN-AlCrN-AlTiCrN - Fig. 2c. The total thickness of the coating is $4.2 \mu \mathrm{m}$. The TiN layer (1) is ca $0.2 \mu \mathrm{m}$ thick, the second $\mathrm{TiCrN}-\mathrm{AlCrN}$ (2) is $2.2 \mu \mathrm{m}$, and the external AlTiCrN (3) layer is $1.8 \mu \mathrm{m}$ thick.

\subsection{Wear measurement}

The wear tests were performed by means of a ball-on-disc SRV friction and wear tester (Schwingungs Reibung und Verschleiss, Optimol Instruments Prüftechnik, Germany) using reciprocating motion of the ball sliding against the coated disc. During the run, the temperature was measured by the thermocouple located in the base plate of the test disc. The disc specimen was $25.4 \mathrm{~mm}$ in diameter and $7.85 \mathrm{~mm}$ thick.

The parameters were selected in such a way as to obtain measurable wear during the test, but also to prevent (a)

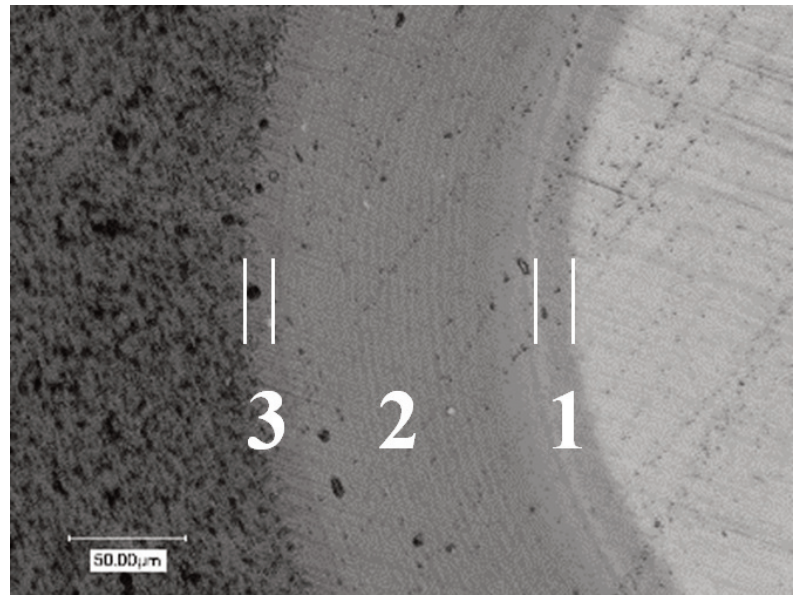

(b)

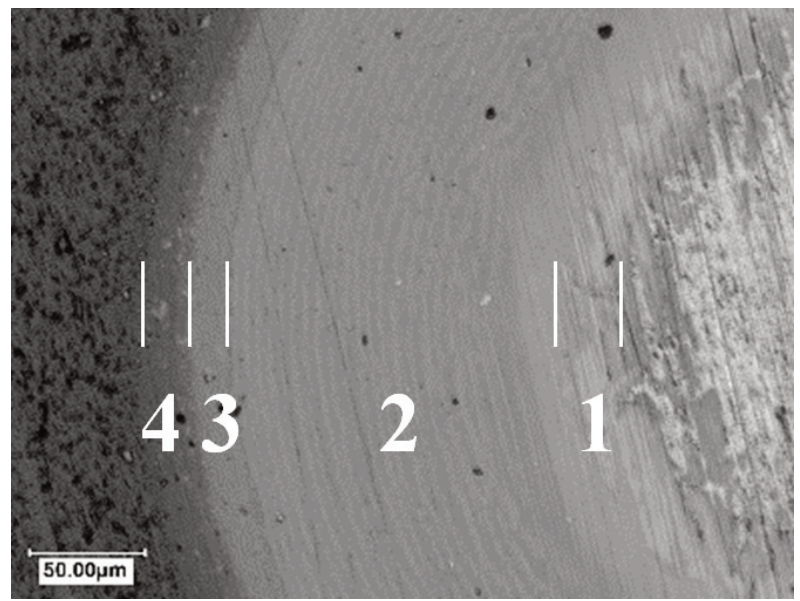

(c)

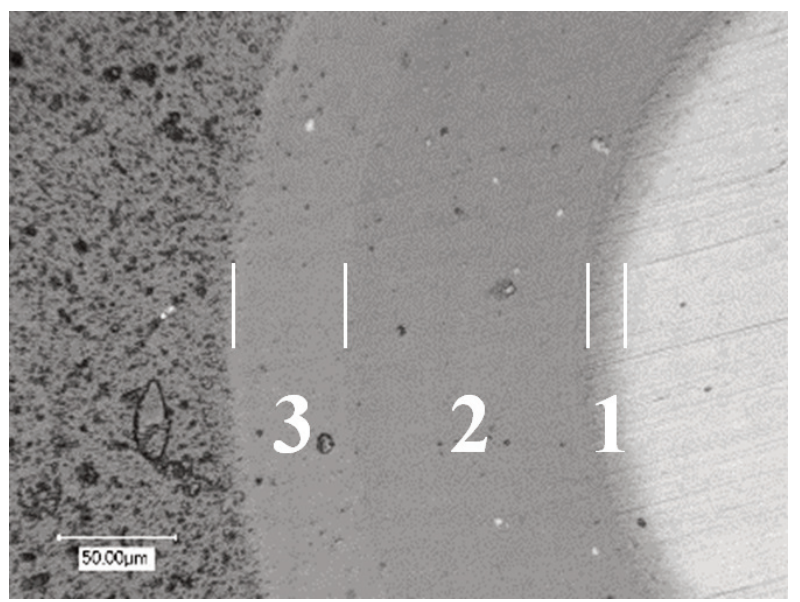

Fig. 2. The structure of the coatings visible at the edges of craters after ball-cratering measurements: (a) "Coating B", (b) "Coating C", (c) "Coating D". 
the coating from being rubbed through (Table 1). The details of the method are described in [15].

The volumetric wear was determined by means of Talysurf CCI - Lite Non-contact 3D Profiler. After the tribological tests, the wear scars were subjected to microscopic analysis. The microstructure of the surface was characterized by images recorded with the Hitachi SU-70 Schottky emission scanning electron microscope (SEM) with a back-scattered electron (BSE) and secondary electron (SE) detection. The research was carried out in vacuum conditions $\left(1 \times 10^{-8} \mathrm{~Pa}\right)$ at an accelerating voltage of $15 \mathrm{kV}$.

\section{RESULTS AND DISCUSSION}

\subsection{Wear measurement}

The results of the wear measurements of four coatings at various temperatures are illustrated in Fig. 3. In each case, volumetric wear (Fig. 3a) and the maximum depth of the wear track (Fig. 3b) depended on the type of the coating and temperature.

Up to $400{ }^{\circ} \mathrm{C}$, the increase in temperature did not significantly accelerate the destruction of any of the tested coatings. At room temperature, the wear of Coating A

Table 1. Test parameters for wear measurements

\begin{tabular}{l|l}
\hline \multicolumn{1}{c}{ Parameter } & \multicolumn{1}{c}{ Value } \\
\hline Load, $\mathrm{N}$, & 5 \\
Stroke, $\mu \mathrm{m}$ & 1000 \\
Frequency, $\mathrm{Hz}$ & 10 \\
Run time, $\mathrm{s}$ & 300 \\
Temperature, ${ }^{\circ} \mathrm{C}$ & $25(\mathrm{RT}), 400,600,750,900$ \\
Temperature gradient, ${ }^{\circ} \mathrm{C} / \mathrm{s}$ & 1 \\
Time of temperature stabilization, s & 1200 \\
Ball material & $\mathrm{Si}_{3} \mathrm{~N}_{4}$ (grade $\left.\mathrm{G} 20\right)$ \\
Ball diameter, mm & 10 \\
No. of repetitions & $\mathrm{min}^{3}$
\end{tabular}

(a)
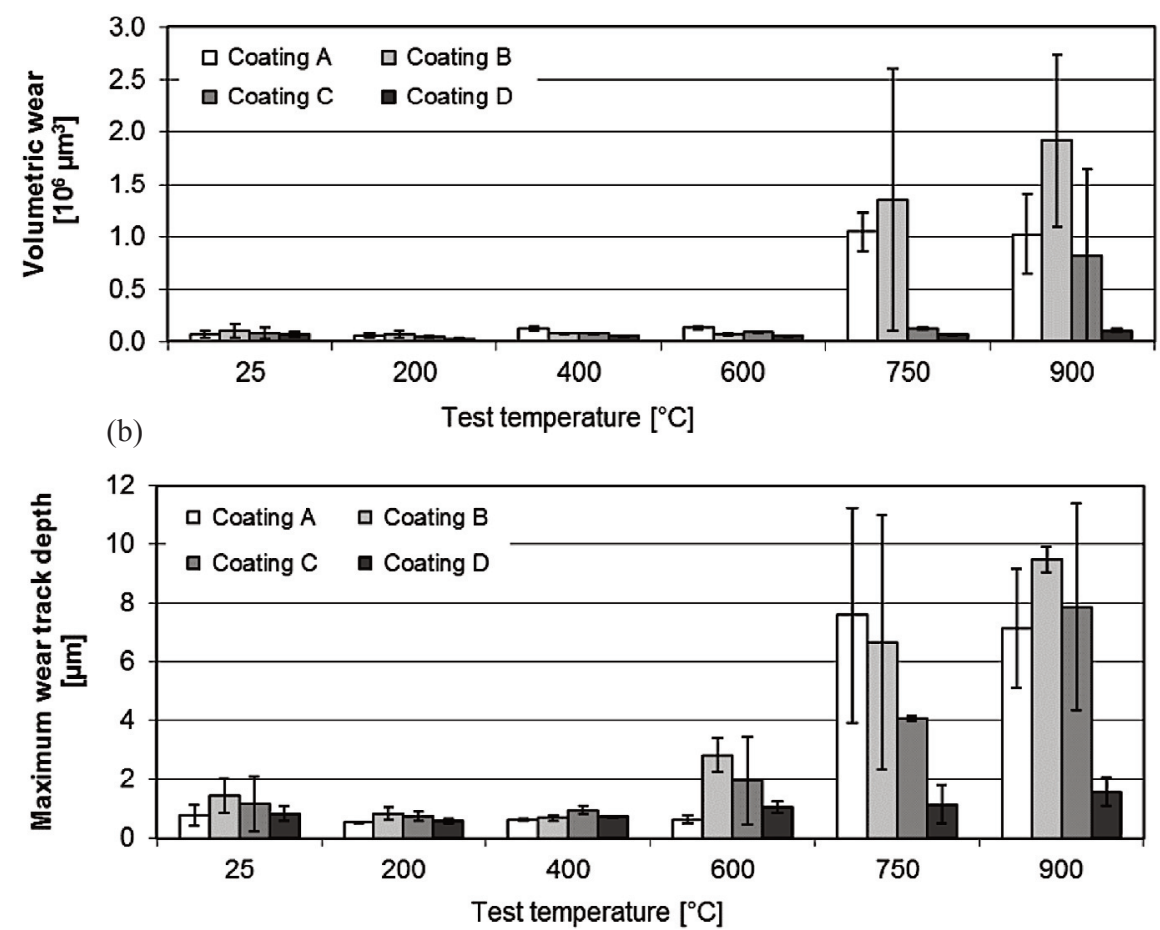

Fig. 3. The disc volumetric wear (a) and maximum wear track depth (b) on tested discs. 
(commercial AlCrN coating) was even lower than the other coatings. At temperature $600^{\circ} \mathrm{C}$, certain increase in maximum wear depth was observed for Coatings B and C. Increase in temperature up to $750{ }^{\circ} \mathrm{C}$ caused radical increase in the wear of Coatings $\mathrm{A}$ and $\mathrm{B}$, while the wear of Coatings $\mathrm{C}$ and $\mathrm{D}$ remained at a relatively low level.
Further increase in temperature up to $900{ }^{\circ} \mathrm{C}$ was destructive for all of the tested coatings apart from Coating D.

The optical images of the wear tracks of the coated discs and the contact areas on $\mathrm{Si}_{3} \mathrm{~N}_{4}$ balls after tests at various temperatures are presented in Fig. 4, SEM images are provided in Fig. 5 and 2D images in Fig. 6.

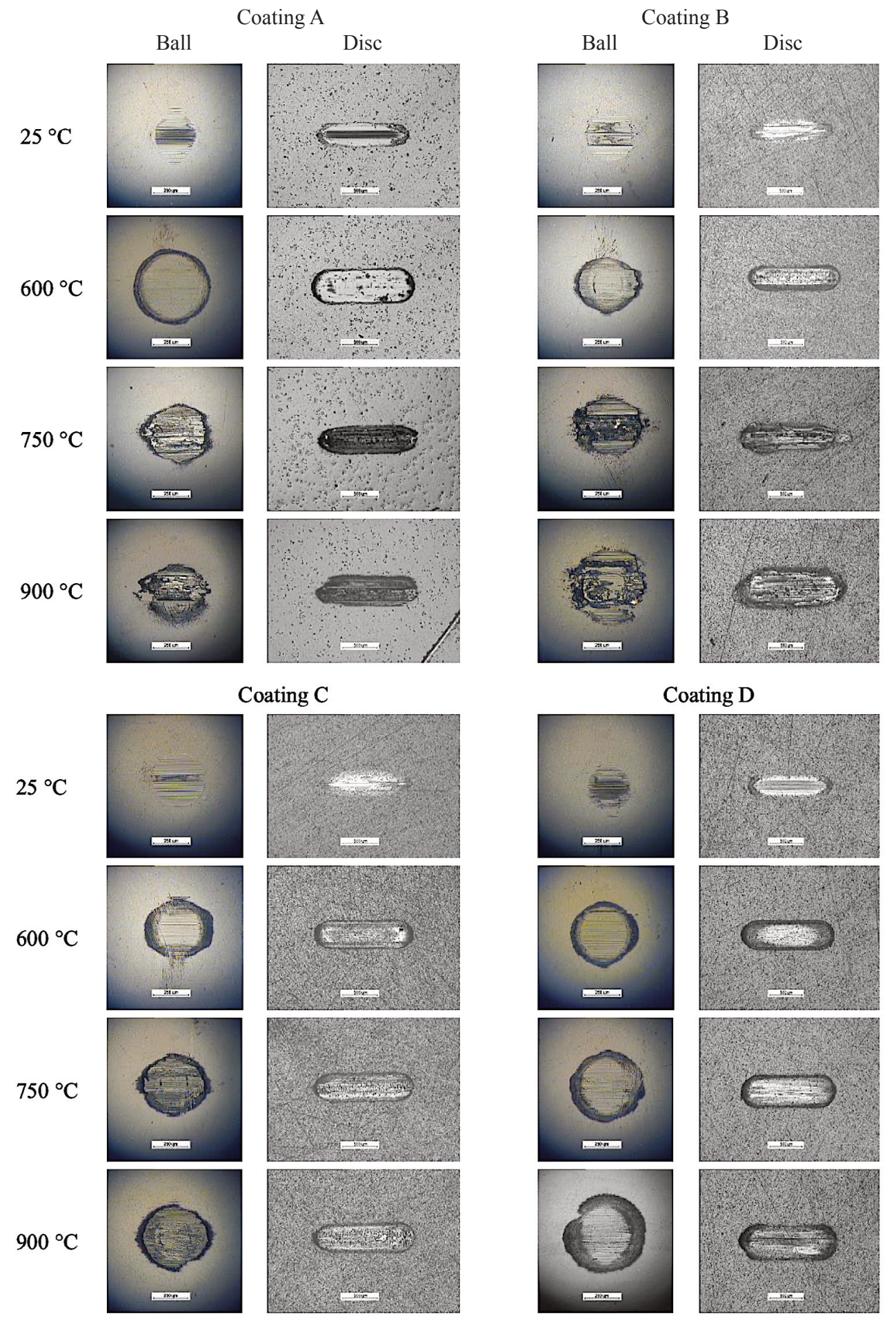

Fig. 4. The wear of the coated disc and the ball after tests at various temperatures. 
(a)

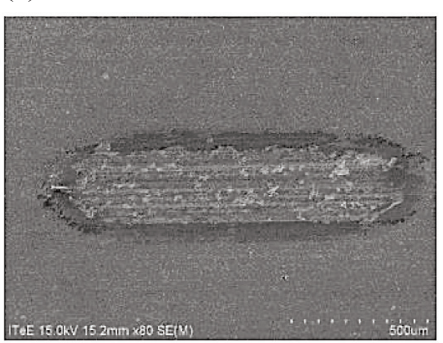

Coating A

Coating B

Coating C

Coating D
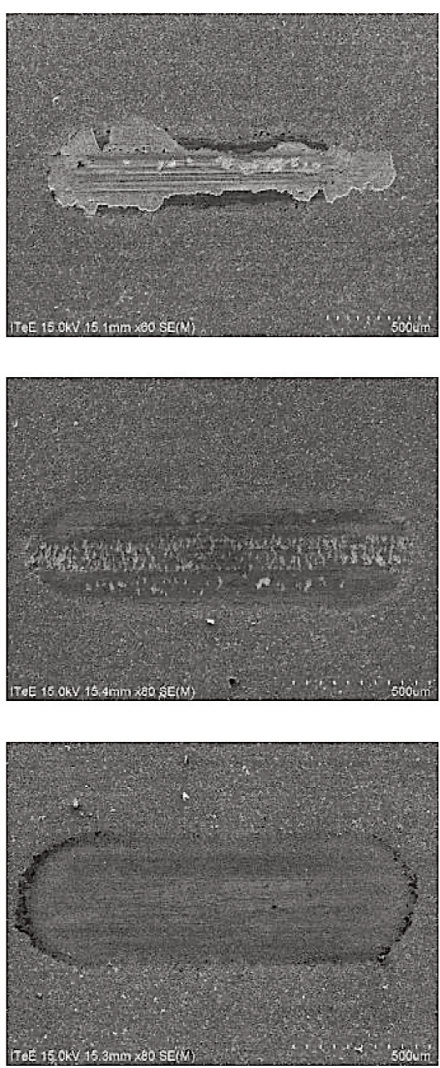

(b)
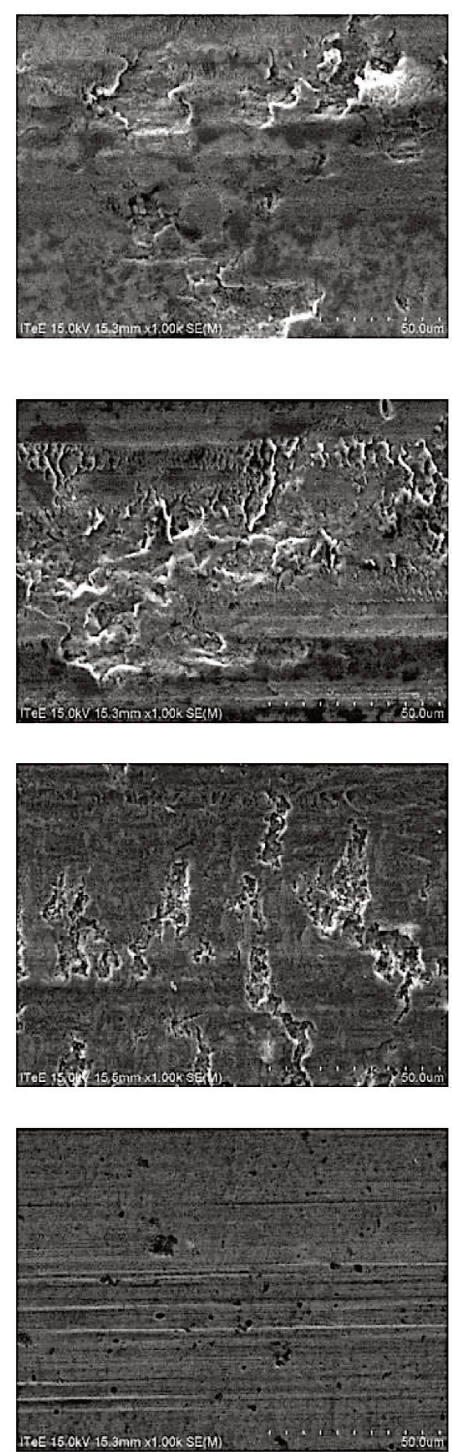

Fig. 5. SEM images of wear tracks on the discs after tests at $750^{\circ} \mathrm{C}$ : (a) wear track, (b) the magnification of the wear track middle section.

For Coating $\mathrm{A}(\mathrm{AlCrN})$, severe wear is visible on the ball and on the coated disc at temperatures exceeding $600{ }^{\circ} \mathrm{C}$. The coating was totally removed and some material was transferred onto the ceramic ball. The depth of the wear track is ca $8 \mu \mathrm{m}$. Further increase in temperature from $750{ }^{\circ} \mathrm{C}$ to $900{ }^{\circ} \mathrm{C}$ does not lead to increase in wear.

Although the sudden increase in wear for Coating $\mathrm{B}$ (TiN-TiCrN-AlCrN-AlCrTiN/Si $3 \mathrm{~N}_{4}$-multilayer) was at the same temperature as for Coating A, i.e. above $600{ }^{\circ} \mathrm{C}$, the wear progress is associated with the delamination of the external layers. The significantly large scatter of the results is caused by the removal of the interlayer of random size. At the test temperature of $750{ }^{\circ} \mathrm{C}$, in some areas the substrate was uncovered, and the maximum wear scar depth reached more than $6 \mu \mathrm{m}$.
Coating $\mathrm{C}$ with external gradient-ON structure was more resistant to high temperature than Coating B. No severe wear was observed up to the maximum test temperature, i.e. $900{ }^{\circ} \mathrm{C}$. However, the volumetric wear remained relatively same at the test temperature of $750{ }^{\circ} \mathrm{C}$, with ca $4 \mu \mathrm{m}$ deep cracks, reaching the substrate in the longitudinal axis of the wear track. A further temperature rise caused increase in wear volume due to the growth in the number and size of cracks.

Coating D with the external layer of AlTiCrN was found to be the most suitable for operating at the high temperature regime. In the whole range of test temperatures from RT (room temperature) up to $900{ }^{\circ} \mathrm{C}$ the coating successfully protected the substrate against severe wear. Even after the test at $900^{\circ} \mathrm{C}$, only shallow scratches 
(a)

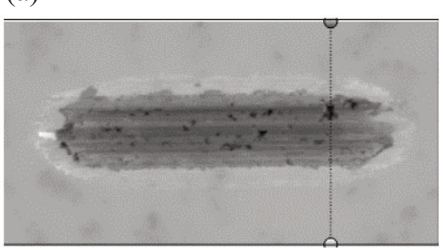

Coating A

Coating B

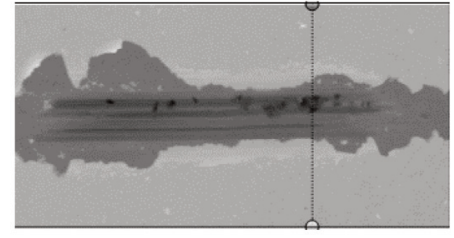

Coating C

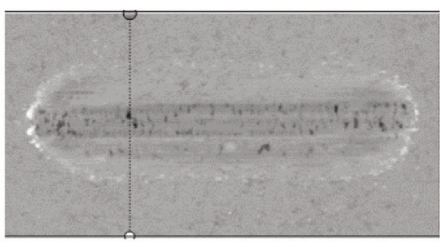

Coating D (b)
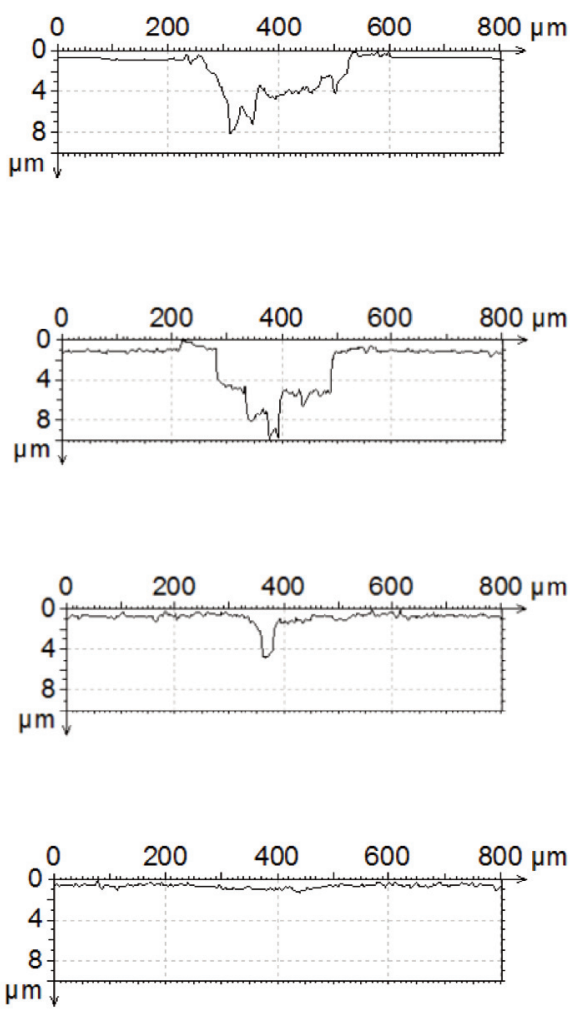

Fig. 6. Wear trace profiles taken from the indicated positions after tests at $750{ }^{\circ} \mathrm{C}$ : (a) wear track, (b) cross-sections.

were visible on the coated surface. Some small holes presented on the surface resulted from the removal of the coating defects.

\section{CONCLUSIONS}

The wear characteristics of the coatings at high temperature depend on their chemical composition and structure. The wear resistance of the developed multilayer coatings (TiN-TiCrN-AlCrN-AlCrTiN/Si ${ }_{3} \mathrm{~N}_{4}$, TiN-TiCrN-AlCrN$\mathrm{AlCrTiN} / \mathrm{Si}_{3} \mathrm{~N}_{4}-\mathrm{AlCrTiSiN}+\operatorname{grad} \mathrm{ON}$, TiN-TiCrN-AlCrNAlTiCrN) described in this study was improved compared with the resistance of the AlCrN-based coating.

For Coating B (TiN-TiCrN-AlCrN-AlCrTiN/Si ${ }_{3} \mathrm{~N}_{4}$ ) at temperatures above $600^{\circ} \mathrm{C}$, the wear process is associated with the delamination of the external layers. Coating C (TiN-TiCrN-AlCrN-AlCrTiN/ $\mathrm{Si}_{3} \mathrm{~N}_{4}$-AlCrTiSiN $+\operatorname{grad} \mathrm{ON})$ with external gradient structure was more resistant to high temperature than Coating $\mathrm{B}$, but at the temperature exceeding $600^{\circ} \mathrm{C}$, there was an increase in wear volume observed due to the growth in the number and size of cracks, the depth of which reached even $4 \mu \mathrm{m}$.
The highest wear resistance up to $900{ }^{\circ} \mathrm{C}$ was denoted for Coating D (TiN-TiCrN-AlCrN-AlTiCrN), in which case across the whole range of test temperatures, only the low intensity abrasive wear was observed.

\section{ACKNOWLEDGEMENTS}

Project HOTselflub was supported by the National Science Centre, Poland, under the M-ERA.NET 2, which received funding from the European Union's Horizon 2020 research and innovation programme, under the grant agreement No. 685451, and by the Estonian Research Council grant M-ERA.Net "HOTselflub" MOBERA18 N.20097582-CA. The publication costs of this article were covered by the Estonian Academy of Sciences and Tallinn University of Technology.

\section{REFERENCES}

1. Torres, H., Ripoll, M. R. and Prakash, B. Tribological behaviour of self-lubricating materials at high temperatures. Int. Mater. Rev., 2018, 63(5), 309-340. https://doi.org/ 10.1080/09506608.2017.1410944 
2. Kumar, R., Liu, L., Antonov, M., Ivanov, R. and Hussainova, I. Hot sliding wear of $88 \mathrm{wt} \%$ TiB-Ti composites from SHS produced powders. Materials, 2021, 14(5), 1242. https://doi.org/ 10.3390/ma14051242

3. Mozgovoy, S., Hardell, J. and Prakash, B. High temperature friction and wear performance of PVD coatings under press hardening contact conditions. Adv. Tribol., 2019, 4981246. https://doi.org/10.1155/2019/4981246

4. Tuszyński, W., Kalbarczyk, M., Michalak, M., Michalczewski, R. and Wieczorek, A. The effect of WC/C coating on the wear of bevel gears used in coal mines. Mater. Sci. (Medžiagotyra), 2015, 21(3), 358-363. https://doi.org/10.5755/j01.ms.21.3.7263

5. Moghaddam, P. V., Prakash, B., Vuorinen, E., Fallqvist, M., Andersson, J. M. and Hardell, J. High temperature tribology of TiAlN PVD coating sliding against 316L stainless steel and carbide-free bainitic steel. Tribol. Int., 2021, 159, 106847. https://doi.org/10.1016/j.triboint.2020.106847

6. Zhang, Z. and Dong, H. A state-of-the-art overview. Recent development in low friction and wear-resistant coatings and surfaces for high-temperature forming tools. Manuf. Rev., 2014, 1, 24. https://doi.org/10.1051/mfreview/2015001

7. Wu, L., Qiu, L., Du, Y., Zeng, F., Lu, Q., Tan, Z., Yin, L., Chen, L. and Zhu, J. Structure and mechanical properties of PVD and CVD TiAlSiN coatings deposited on cemented carbide. Crystals, 2021, 11(6), 598. https://doi.org/10.3390/ cryst11060598

8. Scheerer, H. and Berger C. Wear mechanisms of $(\mathrm{Cr}, \mathrm{Al}, \mathrm{Y}) \mathrm{N}$ PVD coatings at elevated temperatures. Plasma Processes Polym., 2009, 6(S1), S157-S161. https://doi.org/10.1002/ ppap. 200930413

9. Cuao-Moreu, C. A., Alvarez-Vera, M., García-Sánchez, E. O., Maldonado-Cortés, D., Juárez-Hernández, A. and HernandezRodriguez, M. A. L. Characterization of a duplex coating (boriding + sputter-deposited AlCrON) synthesized on an ASTM F-75 cobalt alloy. Thin Solid Films, 2020, 712, 138318. https://doi.org/10.1016/j.tsf.2020.138318

10. Michalczewski, R., Kalbarczyk, M., Mańkowska-Snopczyńska,A., Osuch-Słomka, E., Piekoszewski, W. and Snarski-Adamski, A. et al. The effect of a gear oil on abrasion, scuffing, and pitting of the DLC-coated 18CrNiMo7-6 steel. Coatings, 2019, 9(1), 2. https://doi.org/10.3390/coatings9010002

11. Antonov, M., Hussainova, I., Sergejev, F., Kulu, P. and Gregor, A. Assessment of gradient and nanogradient PVD coatings behaviour under erosive, abrasive and impact wear conditions. Wear, 2009, 267(5), 898-906. https://doi.org/ 10.1016/j.wear.2008.12.045

12. Liu, L., Aydinyan, S., Minasyan, T. and Hussainova, I. SHS produced $\mathrm{TiB}_{2}$-Si powders for selective laser melting of ceramic-based composite. Appl. Sci., 2020, 10(9), 3283. https://doi.org/10.3390/app10093283

13. Michalczewski, R., Kalbarczyk, M., Słomka, Z., Hussainova, I., Liu, L. and Antonov, M. Adhesion of AlCrN coating deposited on $\mathrm{TiB}_{2} / \mathrm{Ti}$ composites sintered by SPS dedicated for high temperature tribological applications. IOP Conf. Ser. Mater. Sci. Eng., 2021, 1140, 012010. https://doi.org/10.1088/1757-899X/1140/1/012010

14. Michalak, M., Michalczewski, R., Osuch-Słomka, E., Maldonado-Cortés, D. and Szczerek, M. The effect of temperature on wear mechanism of the AlCrN coated components. Key Eng. Mater., 2016, 674, 233-238. https://doi.org/ 10.4028/www.scientific.net/KEM.674.233

15. Michalczewski, R., Kalbarczyk, M. and Maldonado-Cortés, D. The method of tribotesting of PVD coated elements in oscillation motion at high temperature. IOP Conf. Ser. Mater. Sci. Eng., 2021, 1140, 012024. https://doi.org/10.1088/1757$899 \mathrm{X} / 1140 / 1 / 012024$

\title{
PVD pinnakattega detailide kulumine kõrgel temperatuuril võnkuva liikumise korral
}

\author{
Remigiusz Michalczewski, Marek Kalbarczyk, Zbigniew Słomka, Sylwia Sowa, Maciej Łuszcz, \\ Edyta Osuch-Słomka, Demófilo Maldonado-Cortés, Le Liu, Maksim Antonov ja Irina Hussainova
}

Antud artikkel annab ülevaate kõrgel temperatuuril töötavate kontaktpindade kulumise vähendamiseks kasutatavate pinnakatete ja modifitseeritud pindade viimastest arengutest. Selle töö eesmärk on olnud uurida sädeplasma paagutuse meetodil (SPS) valmistatud $\mathrm{TiB}_{2} / \mathrm{Ti}$ komposiidi peale PVD-meetodil loodud mitmesugust tüüpi katete kulumist. Uuriti järgmisi katteid: TiN-TiCrN-AlCrN-AlCrTiN/Si ${ }_{3} \mathrm{~N}_{4}$-mitmekihiline, TiN-TiCrN-AlCrN-AlCrTiN/Si $3 \mathrm{~N}_{4}$-AlCrTiSiN+gradient ON, TiN-TiCrN-AlCrN-AlCrN-AlTiCrN ja tööstuslik AlCrN-baasil referentsmaterjal - kõik need on ette nähtud töötamiseks keerulistes kõrgetemperatuursetes töötingimustes. Kulumistestid tehti kuul-plaat SRV hõõrdumis- ja kulumistestriga, liigutades $\mathrm{Si}_{3} \mathrm{~N}_{4}$ kuuli edasi-tagasi mööda kaetud plaati laias temperatuurivahemikus alates toatemperatuurist kuni 900 C. Tulemused näitasid, et kulumiskindlus kõrgel temperatuuril sõltub katete mikrostruktuurist. 